\title{
Lusioersily
}

\section{Assessing the socioeconomic and infrastructure development disparity-a case study of city districts of Punjab, Pakistan}

Rana, I. A., Bhatti, S. S., \& Arshad, H. S. H. (2017). Assessing the socioeconomic and infrastructure development disparity-a case study of city districts of Punjab, Pakistan. International Journal of Urban Sustainable Development, 9(3), 346-358. https://doi.org/10.1080/19463138.2017.1320286

Link to publication record in Ulster University Research Portal

\section{Published in:}

International Journal of Urban Sustainable Development

Publication Status:

Published (in print/issue): 02/09/2017

DOI:

10.1080/19463138.2017.1320286

\section{Document Version}

Author Accepted version

\section{General rights}

Copyright for the publications made accessible via Ulster University's Research Portal is retained by the author(s) and / or other copyright owners and it is a condition of accessing these publications that users recognise and abide by the legal requirements associated with these rights.

\section{Take down policy}

The Research Portal is Ulster University's institutional repository that provides access to Ulster's research outputs. Every effort has been made to ensure that content in the Research Portal does not infringe any person's rights, or applicable UK laws. If you discover content in the Research Portal that you believe breaches copyright or violates any law, please contact pure-support@ulster.ac.uk. 
International Journal of Urban Sustainable Development

Pages 1-13, Accepted 10 Apr 2017, Published online: 21 Apr 2017

http://www.tandfonline.com/doi/full/10.1080/19463138.2017.1320286

doi: $10.1080 / 19463138.2017 .1320286$

\title{
Assessing the socioeconomic and infrastructure development disparity - a case study of city districts of Punjab, Pakistan
}

Irfan Ahmad Rana, Saad Saleem Bhatti, Hafiz Syed Hamid Arshad

\begin{abstract}
Socioeconomic and infrastructure development are the major sectors linked to prosperity of any region, while disparity in these sectors, in certain instances, hinder economic growth. This paper outlines an approach to examine development disparity in both spatial and temporal dimensions. A comparative analyses of socioeconomic and infrastructure development disparity among five city districts of Punjab province of Pakistan helped testing the proposed methods. The data variables and time periods (2002, 2007 and 2012) were selected based on the policy programs introduced by the governments to reflect the closest factual position. Analyses revealed that development disparity prevailed, and the provincial capital (Lahore) remained the most developed. Moreover, the policy scrutiny indicate that despite the introduction of several national level policies and programs, local Municipal Administrations have been incapable at handling the development issues. The proposed approach proved useful, and robust enough to be tested in a different regional setting.
\end{abstract}

Keywords: Development Disparity, Socioeconomic, Infrastructure, Urban, Pakistan

\section{Introduction}

Urbanization is usually defined as the process of growth and expansion of cities and regions that is linked to the rise in population. It is a fast paced phenomenon that cannot be overlooked in a global context. While some researchers consider it a negative thing (Habibi \& Asadi 2011), others believe it to be one of the factors that bring about regional development (Roberts \& Kanaley 2006). Although accelerated and unplanned urbanization often lead to deterioration of living environment (Jaeger et al. 2010), there are, however, some evidences that indicate a positive relationship between urbanization and human development (Njoh 2003). This interesting matter is subject to a myriad of factors, including the pertaining development policies and availability of infrastructure (Irwin \& Bockstael 2004; Castells-Quintana 2016). History shows that urban areas or civilizations always had power, financial resources, facilities and services, whereas inhabitants of rural areas have been seen as simple and hardworking people living close to nature. Capital cities are the richest part in many areas as they are the hub of political power and finances (Roberts 2014). This paradigm has continued in the long run, which consequently created imbalances and disparities within the urban areas, let alone among 
urban, peri-urban or rural areas. In a nutshell, urbanization is instigating pressure on balanced socioeconomic development and provision of infrastructural resources - the problems arising from urbanization are thus attracting great attention from urban planners and policy makers (Frenkel \& Ashkenazi 2008).

Apparently, the urban-rural divide is increasing as large cities are perceived more developed as compared to the rural areas (Liu et al. 2013). Since metropolitans are seen as embodiments of civilization and economic development, research studies on urban settlements are mostly focused on metropolitans and megaregions rather than the smaller cities (Roberts 2014). The comparative development not only varies across space and time, but also among the urban areas. Inequality, therefore, persists between the metropolitans of a same country. Some urban agglomerations (metropolitans), based on sizable population or greater importance, are given priority and more resources as compared to other cities. As a consequence, the potential of smaller cities remain underutilized to tackle rapid urbanization - the same has been shown in a few research studies as well (Rondinelli 1983; Hardoy et al. 2013).

Inequality (also sometimes called disparity) can be defined as an unequal distribution of resources with respect to an area or population, and is considered harmful for economic growth (Rouf \& Jahan 2007). The famous "inverted U” theory by Kuznets showed that economic development increases inequality at the beginning, but decreases after a "turning point" (Kuznets 1955). Some studies indicate that inequality is a significant barrier to prosperity, good quality institutions and higher education (Easterly 2007). However, this is not always true as inequality has been linked to both positive and negative impacts in long run economic growth (Castells-Quintana \& Royuela 2017). Similarly, concentrated urban development influences the economic growth that primarily depends on labour, public access to basic facilities, national policies and institutions (Lewis 1954; Henderson 2003; Lewis 2014; Castells-Quintana 2016). A direct link has also been found between disparities, and economic growth and poverty reduction approaches (Birdsall \& Londoño 1997; Ravallion 2001; Easterly 2007) - this relationship is observed not just in the developing countries (Balisacan \& Fuwa 2004; Goh et al. 2009; Fosu 2011), developed ones also exhibit the very same phenomena (Korpi \& Palme 1998). The increasing inequalities among urban areas is a pressing issue in the modern world as it tends to promote social injustice and environmental degradation. It is thus imperative not only to assess the inequalities, but also to analyse the underlying reasons.

The socioeconomic wellbeing of communities is adversely affected by an increase in poverty and vulnerabilities (Moser 1998; Shorrocks \& Hoeven 2005). Infrastructure is one of the core sectors that directly or indirectly affects the economic development (Holtz-Eakin \& Schwartz 1995; Castells-Quintana 2016) and social wellbeing (Kessides 1993) of a country. Importance of infrastructure is such that it has extensively prejudiced 
decision making processes (Schweikert et al. 2014). Globally, socioeconomic development disparities are increasing between big and small cities that evoke severe implications on a city's capacity to develop and compete for trade and investment (Roberts 2014). The potential of any city's economic growth can therefore be ascertained only through assessment of its level of socioeconomic and infrastructural development disparities. In view of the direct relationship between: (a) sustainable economic growth and poverty reduction strategies, and (b) socioeconomic and infrastructural development levels, it is highly significant to assess the socioeconomic and infrastructural development disparity, and to identify the underlying factors responsible for the inequality. This study proposes an approach to assess socioeconomic and infrastructural development disparity among different cities of a developing country. Five cities at the same level of administrative hierarchy (declared as 'city districts' by provincial government due to large urban agglomerations) in the province of Punjab, Pakistan were selected as the case study area. The disparities were assessed through a number of variables across three points in time (2002, 2007 and 2012) in order to assess the success/failure of urban-related policies and strategies during these time periods. Moreover, this study also highlights the probable reasons behind the lack of success of local authorities in achieving a balanced urban development across the city districts in the study area.

\section{Urbanization in Pakistan}

World Urbanization Prospects (2014) estimates indicate that the proportion of people living in urban areas is more than the rural ones; around 54 percent of the world's population now lives in urban areas. In 1950, 30 percent of the world's population was urban, which, however, is projected to increase to 66 percent by 2050 (United Nations 2014). Achieving sustainable urban development in Asia will be challenging by virtue of rapid population increase and haphazard urbanization (Asian Development Bank 2008). Moreover, haphazard urbanization is also found to induce urban decay, hike in transportation costs, unemployment, environmental degradation, deterioration of agricultural land, an increase in mental illnesses, and even homicide and pandemonium (Gordon \& Richardson 2000).

The history of urbanization in Pakistan can be grasped by looking at the Indus Valley Civilization (Bronze Age civilization: 3300-1300 BCE; mature period 2600-1600 BCE) and historic urban settlements like Mohenjo-Daro (province of Sindh) and Harappa (province of Punjab). The population of the country soared drastically due to high influx of refugees after independence in 1947. Most of the migrants started settling in metropolitans like Karachi and Lahore, however, the cities of Faisalabad, Multan and Rawalpindi also got their share. At present, the province of Punjab is the largest in terms of population with six metropolitans (population over one million), and numerous cities (500,000 to 1 million people) and medium towns (less than 500,000 people). The five major cities of Punjab namely, Lahore, Faisalabad, Multan, Gujranwala and Rawalpindi were also termed as Large Cities by the provincial government (Shah et al. 2007). Figure 
1 shows the spatial distribution of population centres, based on the population size (metropolitans and cities), in Pakistan. Punjab is home to majority of the metropolitans and cities which are quite dispersed across the province. Interestingly, the province of Balochistan, the largest in terms of geographical area, has the smallest population among other provinces of the country, primarily due to mountainous terrain and harsh living environment (scarcity of water).

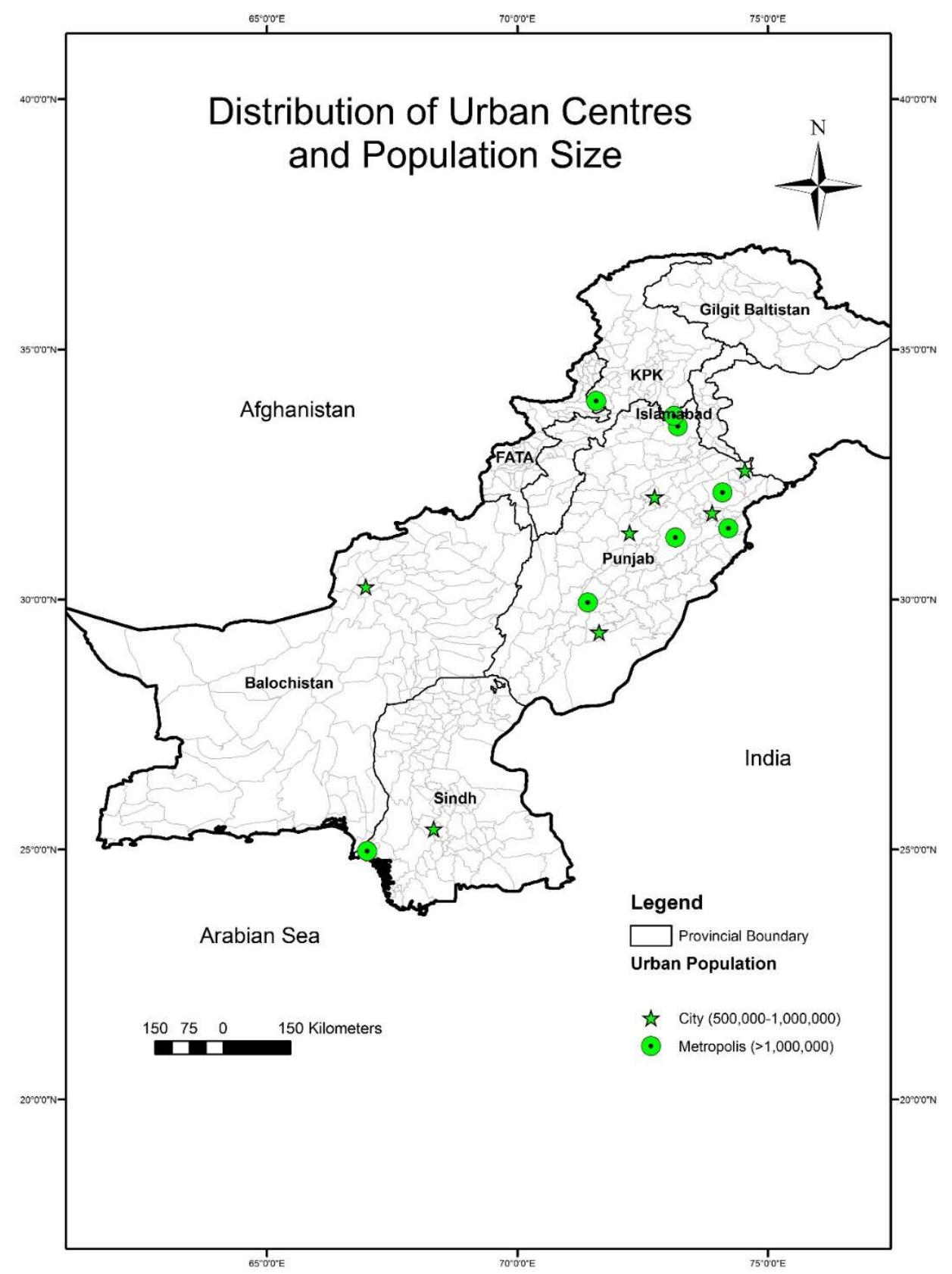

Figure 1. Distribution of urban centres (cities and metropolitans) in Pakistan.

Source: Provincial Development Statistics Reports, Bureau of Statistics Pakistan.

The Census Reports of 1980 \& 1998 outlined that only the areas given the status of "Metropolitan Cooperation / Municipal Cooperation / Municipal Committee / Town 
Committee and Cantonment" will be called urban areas (Pakistan Bureau of Statistics 1998). In addition, separate Development Authorities (DAs) were established under the Cities Development Act of 1976 in large cities of the Punjab province (cities of Lahore, Faisalabad, Gujranwala, Rawalpindi and Multan) to ensure planned and organized urban expansion. The Act explicitly dictates that the DAs and Town Municipal Administrations (TMAs) are responsible for facilitating socioeconomic and infrastructure development in their respective areas. The five large cities of Punjab were given the status of City District as per the Punjab Local Government Ordinance of 2001 that further empowered the local administrations to take development initiatives (Government of Punjab 2001). However, a common framework or integrated strategy for development planning is still missing that cripples all the honest efforts of these Authorities (Shah et al. 2007). The TMAs, in addition to the DAs, are trying to control urban growth and provide infrastructural facilities in their individual capacity. One of the key issues restricting efficient urban planning and development is the absence of physical planning agencies at provincial and/or national levels (Ahmad \& Anjum 2012). Moreover, no comprehensive national/regional urban development plans exists. The Planning Commission of Pakistan introduced five year plans and annual development plan based on sectors like employment, health, education etc., however, the DAs responsible for developing local action areas plans failed to come up with any achievable and realistic plans (Hameed \& Nadeem 2006).

\section{Regional development policies in Pakistan}

As per the National Constitution of Pakistan 1973, regional development pertaining the socioeconomic and infrastructure sectors is the responsibility of the Government; the Government should provide education, health and economic welfare facilities to its citizens. In practice, these responsibilities are divided among federal, provincial and local governments. High tier development sectors such as higher education and industries are managed by the federal government, whereas provincial agencies are responsible for social services like education and health. Local governments are mainly accountable for ensuring infrastructural development. However, the various tiers of government interests seldom fall on the same page.

National development policies are often aimed at reducing imbalances and disparities contemplating rapid urbanization and globalization. Government of Pakistan introduced and implemented several policies for regional development $-\mathrm{a} 6^{\text {th }}$ Five Year Plan was launched in 1980s that focused on rural development. However, previous plans indicate the prevalence of income disparities between urban and rural extents (Planning Commission Government of Pakistan 1983). The District Development Plans were initiated for the first time, and the democratically elected government launched Social Action Plan (SAP) in 1990s to decrease the regional disparity pertaining the socioeconomic sector. It targeted primary healthcare, primary education, food security and nutrition, family planning, and rural water supply and sanitation on priority basis. 
The beginning of new millennium after 2000 saw a readjustment in the development goals; the modification was mainly carried out to align the development goals with the Millennium Development Goals (MDGs) proposed by the United Nations. The Planning Commission of Pakistan, in light of the MDGs, came up with Medium Term Development Framework 2005-2010 (MTDF) that aimed at reducing the regional disparity by "Ensuring Equitable and Balanced development through provision of infrastructure and services, with strengthened local governments under the devolved system". However, the Planning Commission of Pakistan soon after reverted to the Annual Plan systems after 2010 .

The Annual Development Plans of 2010-2011 and 2011-2012 focused on regional development in line with the MDGs, and National Poverty Reduction Strategy. Education reforms, national health policy and spatial strategy were introduced. In addition, National Urban and Regional Policy Research centres were established to measure the development and inequalities. It was observed that despite the efforts by various government and non-government agencies, the imbalance between districts increased over time. Ascertaining the levels of development and provision of public facilities is imperative for examining the socioeconomic development across a region. The current situation in Pakistan, and in particular the province of Punjab which is the most populous in the country, calls for improving the socioeconomic conditions by reducing the human development gap among its cities.

\section{Methods}

Inequality, or disparity, is usually measured through indices that take into account a variety of indicators and variables. Several indices have been derived by various economists and statisticians to measure the level of development or inequality, while international organizations use them extensively for evaluating the development levels across regions or areas. Some of the commonly used indices are Social progress index (Estes \& Morgan 1976), Physical quality of life index (Morris 1979), Gini inequality index (Yitzhaki 1983; Easterly 2007), Theil Index (Theil et al. 1992), Human development Index (Anand \& Sen 1994), Inequality-adjusted Human development index (Hicks 1997), Times Series Theil Index (Conceição \& Galbraith 1998), WHO's Quality of life index (The Whoqol Group 1998) and Infrastructural Development Index (Rana et al. 2017). The GINI index and Theil Index are the ones that are quite frequently used to measure inequality. The applicability of these indices, however, is not always suitable in all the regions primarily due to data limitations. Therefore, the researchers usually need to tune an index in a way so that it suits the regional/local circumstances. Choosing the right indicators remains the most critical part to derive a researcher defined index (Williamson 1965). This study develops and employs the index derived by the authors, where the selection of indicators was mainly based on the policy programs introduced by the provincial government. 


\subsection{Study area}

Most countries have classified their cities or urban settlements based on size. Some categorize them as primary (primate or metropolitans), secondary (second-tier or medium city) or tertiary cities (town), while others simply call them as large, medium or small cities/towns. Population size is still a determining factor in defining the hierarchy level of a city (Roberts 2014). Although a hierarchy of administrative units has been defined in Pakistan (from largest to smallest: country, province, division, district/city district, tehsil/town and union council), all the cities in the country are placed at the same level in this hierarchy. The relative size of the city or urban centre is ignored and all the urban centres are administratively treated on the same level. In the province of Punjab, however, five cities (Lahore, Faisalabad, Gujranwala, Rawalpindi and Multan) based on their large size were distinguished as different from other towns in the province and were classified as City Districts (Figure 2). The five city districts of Punjab comprised the study area for this research. Sub-district, called Town in Punjab administrative system, was used as the unit of analysis where total 39 sub-districts/towns comprised the study area.

The historical city of Lahore is the provincial capital and locally known as the heart of Pakistan. Its city region influence area spans several hundreds of kilometres and encompasses many rural and urban settlements (Rana 2014). The population of the city is on the rise, and the built-up area is expected to increase significantly in the future (Bhatti et al. 2015). The city is host to a variety of industries are businesses, and is composed of 10 towns including a cantonment. It is the largest among the other four city districts in terms of population (Figure 3). City district Faisalabad, composed of 8 towns, is the second largest and is famous for textile industries. Agro-industrial based economy is prevalent in city districts Gujranwala (7 towns) and Multan (6 towns), whereas Rawalpindi ( 8 towns) boasts mix functions. Figure 3 shows how the population has increased over time in these five city districts. 


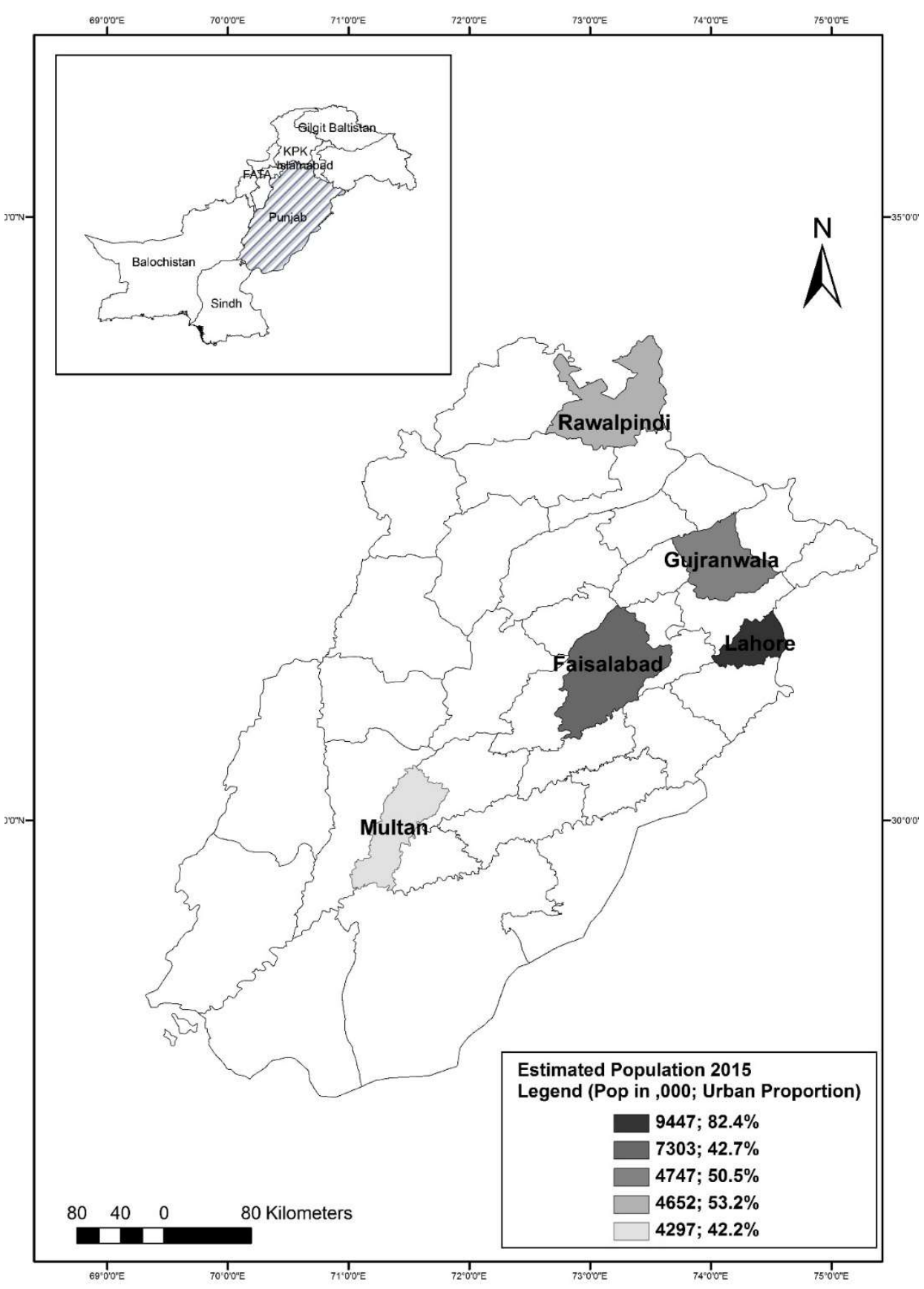

Figure 2. The city districts of Punjab, Pakistan, and their overall urban populations. Source: Punjab Development Statistics 2015 (Punjab Bureau of Statistics 2015) 


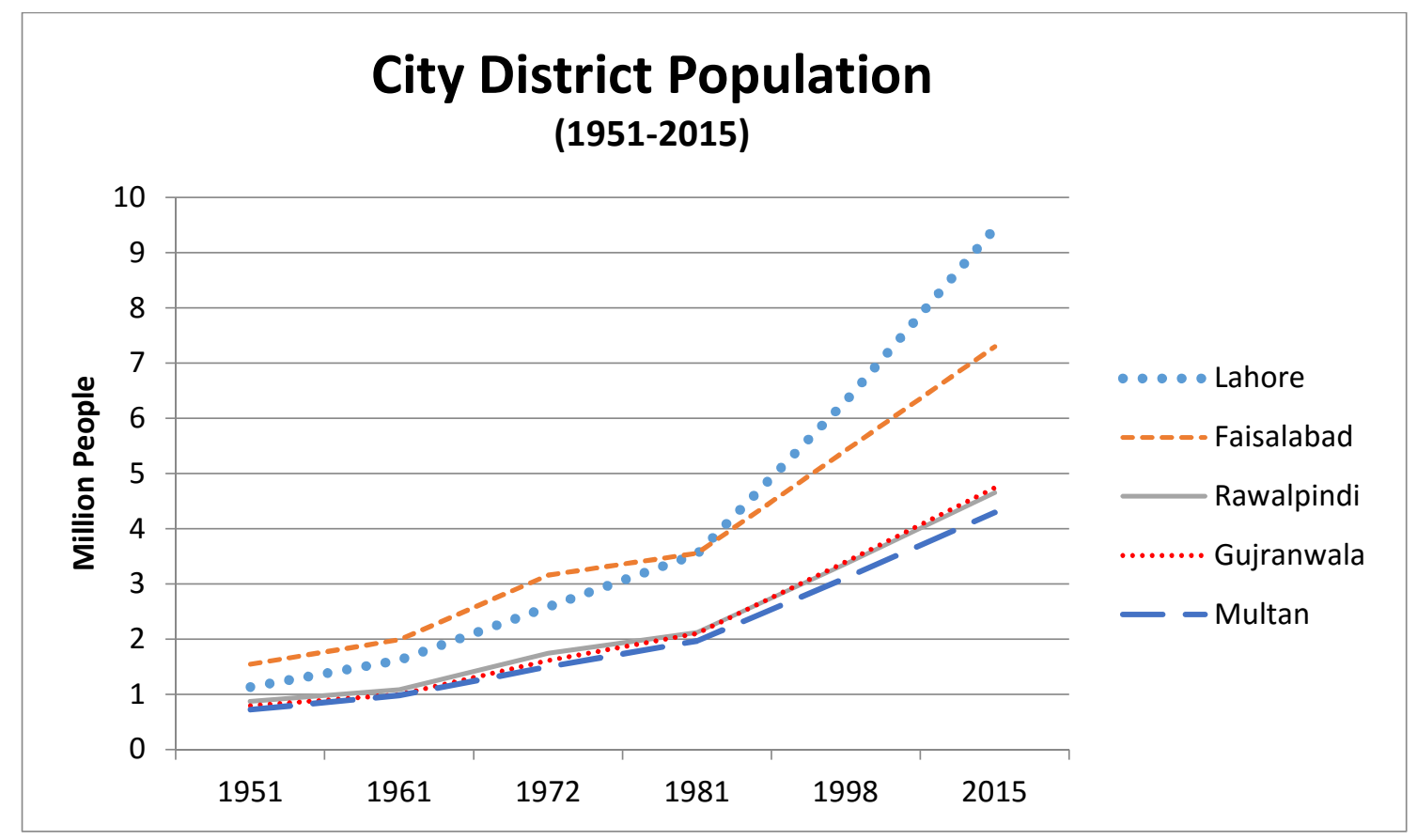

Figure 3. Population growth in city districts of Punjab, Pakistan during 1951-2015. Source: Punjab Development Statistics 2015 (Punjab Bureau of Statistics 2015)

\subsection{Variables and analytical methods}

The socioeconomic and infrastructure development disparity among the five city districts of the study area was examined through a quantitative and comparative approach. A variety of data indicators were used where the selection of indicators was primarily based on the policy programs to imitate the best probable depiction of development status in the sub-districts during 2002, 2007 and 2012. The time-series data was extracted from the Punjab Development Statistics (PDS) and Multiple Indicator Cluster Survey (MICS) reports collected from the Bureau of Statistics, Government of Punjab. A total 12 indicators were used: 7 to develop an index to measure socioeconomic development and 5 to develop an index to quantify infrastructure development (Table 1). A composite index was later developed to depict the overall development status in the five city districts. 
Table 1. Socioeconomic and infrastructure development indicators selected for this study.

\begin{tabular}{|c|c|c|c|}
\hline Sector & Component & Indicators & Source* \\
\hline \multirow{5}{*}{ Socioeconomic } & Income & $\begin{array}{l}\text { - Percentage of Population (above } 15 \\
\text { years) employed } \\
\text { - Percentage of households own house } \\
\text { (dwelling) }\end{array}$ & MICS \\
\hline & \multirow[t]{2}{*}{ Education } & $\begin{array}{l}\text { - Adult literacy rate (15 years or older) } \\
\text { in percentage } \\
\text { - Enrolment rate at primary school in } \\
\text { percentage }\end{array}$ & MICS \\
\hline & & $\begin{array}{l}\text { - Number of colleges (all types) per } \\
100,000 \text { population }\end{array}$ & PDS \\
\hline & \multirow{2}{*}{ Health } & $\begin{array}{l}\text { - Percentage of adequate fed infants to } \\
\text { malnourished infants }\end{array}$ & MICS \\
\hline & & $\begin{array}{l}\text { - Number of hospital beds (all medical } \\
\text { institutions) per } 100,000 \text { population. }\end{array}$ & PDS \\
\hline Infrastructure & $\begin{array}{l}\text { Accessibility } \\
\text { to amenities }\end{array}$ & $\begin{array}{l}\text { - Percentage of households having } \\
\text { access to secondary school (within } \\
5 \mathrm{~km} \text { ) } \\
\text { - Percentage of households having } \\
\text { access to electricity } \\
\text { - Percentage of households using gas as } \\
\text { cooking fuel } \\
\text { - Percentage of households having } \\
\text { improved water source for drinking } \\
\text { water } \\
\text { - Percentage of households having } \\
\text { improved sanitation }\end{array}$ & MICS \\
\hline
\end{tabular}

MICS = Multiple Indicator Cluster Survey Reports (Punjab Bureau of Statistics 2004; Punjab Bureau of Statistics 2009; Punjab Bureau of Statistics 2011)

PDS = Punjab Development Statistics Reports (Punjab Bureau of Statistics 2005; Punjab Bureau of Statistics 2008; Punjab Bureau of Statistics 2012)

It is worth mentioning that the data considered as representative of 2002, 2007 and 2012 was extracted, respectively, from the 2003-04, 2007-08 and 2011 (unpublished) MICS reports and 2005, 2008 and 2012 PDS reports. It should also be noted that some of the data was not available at sub-district/town level, which, however, was available at city district scale. This includes the 2002 data extracted from MICS report (mainly comprising data values in percentage) for the city districts of Faisalabad, Gujranwala, Multan and Rawalpindi, and a few towns of Lahore namely Wahga, Samanabad and Gulberg. Since the data of these areas for the said time period (2002) was available at city district scale, 
the same data values as of the city district were used for the respective sub-districts/towns for further analysis.

Composite Indices were prepared using the data standardization method 0-1 (zero to one) Transformation Technique for the socioeconomic and infrastructure development indicators - an aggregate of the two was also formulated to examine the overall level of development in the sub-districts/towns. The rescaled data of indicators was either positive or neutral, where the higher value (closest to 1) indicated ideally best developed while the values close to 0 denoted least level of development.

Transformed Value $(\mathrm{TV})=\mathrm{X}_{\mathrm{ij}}-\mathrm{X}_{\mathrm{i}}(\min ) / \mathrm{X}(\max )-\mathrm{X}(\min )$

Where

$$
\begin{array}{ll}
X i j= & \text { Value of } i^{\text {th }} \text { indicator in } j^{\text {th }} \text { sub-district } \\
X(\min )= & \text { Minimum value in subjected indicator } \\
X(\max )= & \text { Maximum value in subjected indicator }
\end{array}
$$

In addition to ascertaining the levels of development in spatial dimension though the aforementioned indices, statistical tests were also utilized to examine the development trend during different time periods. Sample paired t-test and coefficient of variance were used to identify sectoral and temporal development disparity trends in the study area during 2002-2007, 2007-2012 and 2002-2012. The policies and programs assisting reduction in development disparity were identified.

\section{Results and discussion}

Analyses have confirmed that Lahore (provincial capital) has been far more developed among all the city districts of Punjab, especially in the infrastructural sector where huge development disparity was observed. It is closely tailed by Gujranwala and Faisalabad city districts. Multan and Rawalpindi areas were found to be the least developed among the five city districts. Interestingly, the level of development in the study area was found to have some sort of spatial dependency with the provincial capital - the closer the city district to Lahore, the more it is developed. Most of the sub-districts of Lahore surpassed in development throughout the time period (2002-2012) in every sector and indicator. The composite index developed in this study showcases the levels of infrastructure, socioeconomic and overall development (incorporating all chosen indicators) in the study area during the selected time periods of 2002, 2007 and 2012 (Table 2). 
Table 2. Socioeconomic, infrastructure and composite development index of city districts of Punjab, Pakistan at sub-district/town level during 2002, 2007 and 2012.

\begin{tabular}{|c|c|c|c|c|c|c|c|c|c|c|c|}
\hline \multirow{2}{*}{$\begin{array}{l}\text { Sr } \\
\text { No }\end{array}$} & \multirow{2}{*}{$\begin{array}{l}\text { City } \\
\text { District }\end{array}$} & \multirow{2}{*}{ Sub-District } & \multicolumn{3}{|c|}{2002} & \multicolumn{3}{|c|}{2007} & \multicolumn{3}{|c|}{2012} \\
\hline & & & Socio & Infra & CI & Socio & Infra & CI & Socio & Infra & CI \\
\hline 1 & \multirow{8}{*}{ Faisalabad } & Chak Jhumra Town & 0.48 & 0.87 & 0.67 & 0.68 & 0.36 & 0.52 & 0.43 & 0.73 & 0.58 \\
\hline 2 & & Jaranwala Town & 0.46 & 0.83 & 0.64 & 0.48 & 0.34 & 0.41 & 0.29 & 0.64 & 0.47 \\
\hline 3 & & Jinnah Town & 0.48 & 0.85 & 0.66 & 0.53 & 0.46 & 0.49 & 0.39 & 0.64 & 0.52 \\
\hline 4 & & Lyallpur Town & 0.48 & 0.88 & 0.68 & 0.53 & 0.40 & 0.47 & 0.37 & 0.78 & 0.58 \\
\hline 5 & & Madina Town & 0.48 & 0.85 & 0.66 & 0.46 & 0.47 & 0.46 & 0.39 & 0.60 & 0.49 \\
\hline 6 & & Iqbal Town & 0.48 & 0.85 & 0.66 & 0.48 & 0.42 & 0.45 & 0.39 & 0.49 & 0.44 \\
\hline 7 & & Summundari Town & 0.48 & 0.88 & 0.68 & 0.46 & 0.29 & 0.38 & 0.39 & 0.63 & 0.51 \\
\hline 8 & & Tandlianwala Town & 0.46 & 0.78 & 0.62 & 0.38 & 0.18 & 0.28 & 0.32 & 0.51 & 0.42 \\
\hline 9 & \multirow{7}{*}{ Gujranwala } & Aroop Town & 0.52 & 0.93 & 0.72 & 0.40 & 0.73 & 0.57 & 0.62 & 0.88 & 0.75 \\
\hline 10 & & Kamoke Town & 0.51 & 0.93 & 0.72 & 0.44 & 0.63 & 0.53 & 0.61 & 0.87 & 0.74 \\
\hline 11 & & Khiali Shahpur Town & 0.52 & 0.92 & 0.72 & 0.44 & 0.68 & 0.56 & 0.60 & 0.89 & 0.74 \\
\hline 12 & & Nandipur Town & 0.52 & 0.90 & 0.71 & 0.46 & 0.70 & 0.58 & 0.62 & 0.88 & 0.75 \\
\hline 13 & & $\begin{array}{l}\text { Nowshera Virkan } \\
\text { Town }\end{array}$ & 0.51 & 0.94 & 0.72 & 0.39 & 0.53 & 0.46 & 0.60 & 0.85 & 0.72 \\
\hline 14 & & $\begin{array}{l}\text { Qila Dildar Singh } \\
\text { Town }\end{array}$ & 0.52 & 0.93 & 0.73 & 0.36 & 0.74 & 0.55 & 0.61 & 0.88 & 0.74 \\
\hline 15 & & Wazirabad Town & 0.51 & 0.96 & 0.74 & 0.37 & 0.57 & 0.47 & 0.61 & 0.87 & 0.74 \\
\hline 16 & \multirow{10}{*}{ Lahore } & Lahore Cantt & 0.45 & 0.59 & 0.52 & 0.43 & 0.97 & 0.70 & 0.48 & 0.94 & 0.71 \\
\hline 17 & & Aziz Bhatti Town & 0.44 & 0.87 & 0.65 & 0.60 & 0.77 & 0.68 & 0.57 & 0.83 & 0.70 \\
\hline 18 & & Data Ganj Bukhsh & 0.61 & 0.81 & 0.71 & 0.47 & 0.98 & 0.72 & 0.51 & 0.99 & 0.75 \\
\hline 19 & & Allama Iqbal Town & 0.54 & 0.69 & 0.61 & 0.46 & 0.78 & 0.62 & 0.49 & 0.92 & 0.71 \\
\hline 20 & & Nishtar Town & 0.52 & 0.92 & 0.72 & 0.43 & 0.71 & 0.57 & 0.48 & 0.91 & 0.70 \\
\hline 21 & & Ravi Town & 0.49 & 0.92 & 0.71 & 0.35 & 0.95 & 0.65 & 0.46 & 0.98 & 0.72 \\
\hline 22 & & Shalimar Town & 0.57 & 0.95 & 0.76 & 0.63 & 0.87 & 0.75 & 0.61 & 0.96 & 0.78 \\
\hline 23 & & Wahga Town & 0.55 & 0.94 & 0.74 & 0.61 & 0.72 & 0.66 & 0.53 & 0.86 & 0.70 \\
\hline 24 & & Samanabad Town & 0.51 & 0.90 & 0.71 & 0.52 & 0.93 & 0.72 & 0.51 & 0.99 & 0.75 \\
\hline 25 & & Gulberg Town & 0.53 & 0.78 & 0.66 & 0.58 & 0.92 & 0.75 & 0.52 & 0.99 & 0.75 \\
\hline 26 & \multirow{6}{*}{ Multan } & Boson Town & 0.29 & 0.33 & 0.31 & 0.37 & 0.59 & 0.48 & 0.21 & 0.54 & 0.38 \\
\hline 27 & & Mumtazabad Town & 0.29 & 0.38 & 0.33 & 0.39 & 0.58 & 0.48 & 0.21 & 0.69 & 0.45 \\
\hline 28 & & Shah Rukan-e-Alam & 0.29 & 0.32 & 0.30 & 0.40 & 0.63 & 0.52 & 0.22 & 0.64 & 0.43 \\
\hline 29 & & Sher Shah Town & 0.29 & 0.41 & 0.35 & 0.47 & 0.60 & 0.53 & 0.21 & 0.65 & 0.43 \\
\hline 30 & & Jalalpur Pirwala Town & 0.28 & 0.24 & 0.26 & 0.19 & 0.38 & 0.28 & 0.13 & 0.40 & 0.27 \\
\hline 31 & & Shujabad Town & 0.28 & 0.16 & 0.22 & 0.32 & 0.41 & 0.36 & 0.18 & 0.45 & 0.31 \\
\hline 32 & \multirow{8}{*}{ Rawalpindi } & Gujjar Khan Town & 0.40 & 0.87 & 0.63 & 0.52 & 0.47 & 0.50 & 0.69 & 0.53 & 0.61 \\
\hline 33 & & Kahuta Town & 0.47 & 0.62 & 0.54 & 0.60 & 0.43 & 0.52 & 0.74 & 0.34 & 0.54 \\
\hline 34 & & Kotli Sattian Town & 0.53 & 0.61 & 0.57 & 0.79 & 0.14 & 0.46 & 0.86 & 0.21 & 0.54 \\
\hline 35 & & Murree Town & 0.53 & 0.80 & 0.67 & 0.68 & 0.41 & 0.55 & 0.81 & 0.51 & 0.66 \\
\hline 36 & & Rawal Town & 0.40 & 0.84 & 0.62 & 0.45 & 0.74 & 0.60 & 0.64 & 0.69 & 0.66 \\
\hline 37 & & Potohar Town & 0.43 & 0.91 & 0.67 & 0.64 & 0.50 & 0.57 & 0.77 & 0.53 & 0.65 \\
\hline 38 & & Kallar Sayaddan Town & 0.58 & 0.78 & 0.68 & 0.51 & 0.36 & 0.43 & 0.75 & 0.63 & 0.69 \\
\hline 39 & & Taxila Town & 0.40 & 0.86 & 0.63 & 0.42 & 0.72 & 0.57 & 0.56 & 0.76 & 0.66 \\
\hline
\end{tabular}

CI = Overall Development Composite Index

Socio $=$ Socioeconomic Development Index

Infra $=$ Infrastructure Development Index 
Average index values were also calculated to observe the temporal development trend from a different perspective. It can be deduced that city district Rawalpindi crossed other cities in terms of socioeconomic development during 2012 (Figure 4(a)), whereas Lahore outpaced all other city districts in terms of infrastructure development (Figure 4(b)). Figures 4 and 5 also indicate an overall trend of downward plunge in the development sectors from 2002 to 2007, which, however surged during 2007 and 2012 (Figures 4 and 5 ). This anomaly can be attributed to the data limitation mentioned in Section 4.2; the 2002 data of majority of the study area was not available at sub-district/town level and the same data values as of the city district were used for these areas for further analysis. The general trend (ignoring the 2002), apparently, indicates that the relative development disparity in the infrastructure sector has decreased in the study area (Figure 4(b)), which is also consistent with another study (Rana et al. 2017). The findings of the study in socioeconomic development sector, however, are quite different compared to the infrastructure domain - the highest development was observed in Gujranwala and Lahore city districts (Figure 4(a)). Faisalabad and Multan areas exhibited a reduction in this sector during 2007 and 2012, thus increasing the development disparity.

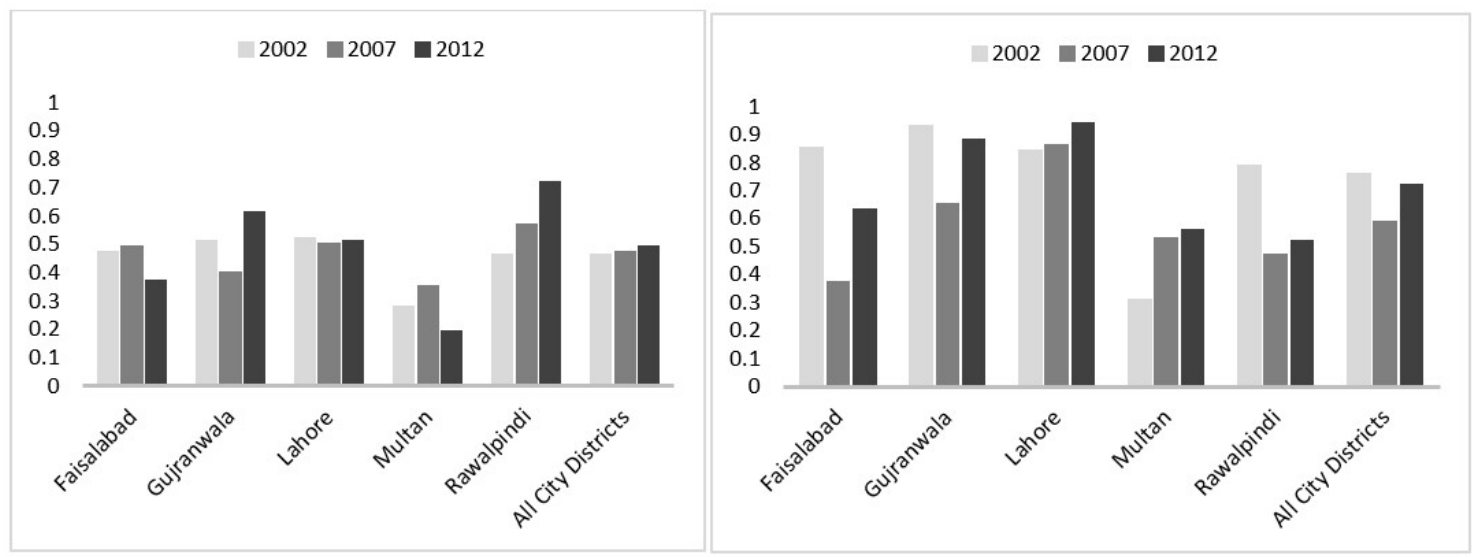

(a)

(b)

Figure 4. Average development value for (a) socioeconomic and (b) infrastructure sectors in city districts of Punjab, Pakistan.

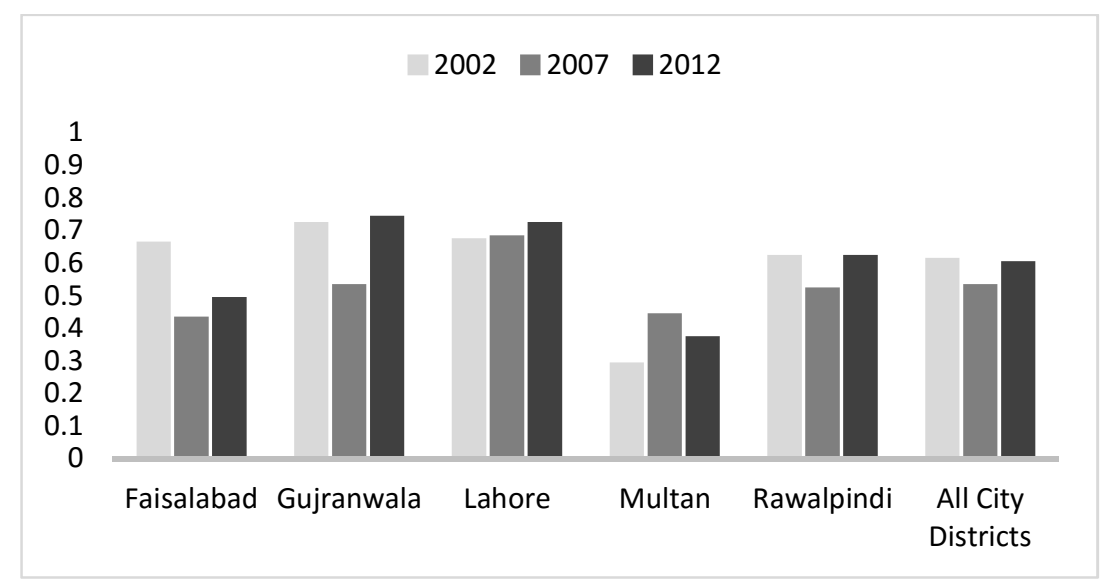

Figure 5. Average overall development value in city districts of Punjab, Pakistan. 
Speaking of the development variance within the study area, the infrastructure sector showed $33.22 \%$ variance in 2002 , which reduced to $32.7 \%$ in 2007 , and then to $27.12 \%$ in 2012. This clearly indicates a reduction in infrastructure development disparity during 2002 and 2012. The variance in the socioeconomic development sector did not exhibit a uniform trend; it reduced from $27.72 \%$ in 2002 to $18.83 \%$ in 2007 , and later increased to $43.15 \%$ in 2012. This upsurge in variance in the socioeconomic development indicates that the disparity in this sector is on the rise in the study area. The overall, or cumulative development trend also indicates a fluctuating variance from $29.14 \%$ to $19.27 \%$ to 26.71\% during 2002, 2007 and 2012, respectively (Figure 5). It can be inferred that overall, the development disparity has been fluctuating during the 2002-2012 decade. However, this finding needs to be taken with a grain of salt considering the spatial scale limitation of the 2002 data.

The inter-town development, or the development within each city district, has been highly significant during 2002 and 2012 (Table 3). Although some fluctuating development trend has been observed that can again be attributed to the 2002 data limitation, the overall development in the study area has improved. Growth in city district Faisalabad declined during 2002 and 2007, but later recovered, whereas Gujranwala and Rawalpindi areas showed highly significant and positive development trend during 2007 and 2012. Lahore and Multan exhibited great improvement in socioeconomic and infrastructural developments throughout all the time periods. On the whole, development was highly significant in all the city districts from 2007 to 2012; it can be inferred that this time period has been the most fruitful (among the time periods considered in this study) in terms of development in the study area.

As mentioned earlier, proximity to the provincial capital might be a determining factor for development in Punjab province. Despite the policy programs and projects aimed at reducing development inequality, disparity still somewhat prevails in the study area. However, considering the exponential population growth and urban expansion, the local government agencies must be admired for their efforts to improve the socioeconomic and infrastructure sectors. This is especially true for the provincial capital Lahore, the city with a population of more than ten million; people from other cities prefer to migrate to the provincial capital because of ease of access to exceptionally good facilities. 
Table 3. Temporal development trend in city districts of Punjab, Pakistan during 20022007, 2007-2012 and 2002-2012.

\begin{tabular}{|c|c|c|c|}
\hline City District & 2002 and 2007 & 2007 and 2012 & 2002 and 2012 \\
\hline \multicolumn{4}{|c|}{ Socioeconomic Sector } \\
\hline Faisalabad & -0.868 & $5.261^{*}$ & $8.117^{*}$ \\
\hline Gujranwala & $7.641^{*}$ & $-13.816^{*}$ & $-27.396^{*}$ \\
\hline Lahore & 0.470 & -0.543 & 0.244 \\
\hline Multan & -1.863 & $6.123 * *$ & $8.026^{*}$ \\
\hline Rawalpindi & -2.929 & $-8.752^{*}$ & $-10.771^{*}$ \\
\hline All City Districts & -0.845 & -0.777 & -1.479 \\
\hline \multicolumn{4}{|c|}{ Infrastructure Sector } \\
\hline Faisalabad & $16.639 *$ & $-6.137 *$ & $7.780^{*}$ \\
\hline Gujranwala & $7.979 *$ & $-8.707 *$ & $5.050 *$ \\
\hline Lahore & -0.394 & $-3.524 *$ & $-2.274 * *$ \\
\hline Multan & $-9.295^{*}$ & -1.418 & $-9.600 *$ \\
\hline Rawalpindi & $6.237^{*}$ & -1.418 & $6.457^{*}$ \\
\hline All City Districts & $3.885^{*}$ & $-6.406^{*}$ & 1.292 \\
\hline \multicolumn{4}{|c|}{ Overall Sectors } \\
\hline Faisalabad & $10.211^{*}$ & $-3.442 * *$ & $10.050 *$ \\
\hline Gujranwala & 9.983* & $-14.769 *$ & $-3.879 *$ \\
\hline Lahore & $-0.148 * *$ & $-3.419 *$ & -2.252 \\
\hline Multan & -5.597 & 4.635 & -4.518 \\
\hline Rawalpindi & $4.413 * *$ & $-4.180 * *$ & 0.105 \\
\hline All City Districts & $3.337 * *$ & $-4.783 *$ & 0.339 \\
\hline
\end{tabular}

The MTDF and the Annual Development Plans were in effect during the time span of 2002-2012 that focused on achieving the MDGs. Based on the review, it was observed that the policies had fragmented effects on regional development disparity. Some programs helped reducing regional disparity at the beginning, however, repeated amendments effectuated negative to no effect. Results of this study indicate that although the level of development disparity decreased in almost all the indicators of socioeconomic and infrastructural sectors, inequality still prevails in the study area. National development programs for provision of electricity, clean water and sanitation facilities, however, have been partially successful at reducing development disparity among the city districts. Programs and policies like strategic national water supply and sanitation plan, and Khushal Pakistan (meaning prosperous Pakistan) for gas and electricity have helped in provision of amenities, whereas national low cost housing and mass housing programme, maternal and infant nutrition programme, and national education policy have provided for socioeconomic development. Inequality, however, still endures in the cities of Punjab province. In addition, national development plans are oriented more towards 
the infrastructure development rather than the socioeconomic sector (Rana 2014). The policy instructions are usually forwarded from the national/federal level to the provincial level. Provinces interpret them in their own ways, and propagate the programs to district administrations. By the time a program reaches the locals, the funding and technical knowledge becomes inadequate, and the programs are no longer in line with the Vision Plans projected by the Planning Commission. All these tiers of government have their own agendas and interests that adversely affect the development programs necessitating implementation by local agencies for public welfare.

\section{Conclusion}

Cities are generally way more developed than rural areas; this contrast is more pronounced in the developing countries. The level of development disparity among urban centres serves as an indicator to the (probable) situation in the rural areas. This study proposes an approach to examine the development disparity in the socioeconomic and infrastructure sectors. The findings of the case study application of this approach signifies that the policy programs introduced by the government have dispersed effects on socioeconomic and infrastructure development disparity in the study area (city districts of Punjab). Although the overall development disparity reduced during 2002 and 2012, it still vestiges high significance among the towns. Examining the two eras, 2002-2007 and 2007-2012, indicates that the annual development plans have been more successful as compared to five-year plans at controlling/reducing the development disparity. Policies/programs relating the development of sanitation facilities and provision of electricity are deemed the most successful. In fact, provision to clean water and sanitation facilities has been among the highly achieved goals of the MDGs in Pakistan. One of the main reasons for persistent development disparity can be, however, attributed to the fragmented and overlapping jurisdictions of development authorities and local administrations which have resulted in chaos and confusion (Shah et al. 2007; Ahmad \& Anjum 2012). Since this study helps identifying the less developed sub-districts/towns, provincial government could initiate and implement special action plans to mitigate the situation in the deprived areas. Though, in-depth policy analysis and proper understanding of the socio-political conditions still remains imperative to effectively implement any policy programs. In lieu of the above discussions and findings, a more detailed data analysis can be done by incorporating more indicators from social, economic and environment dimensions. Moreover, this study can be replicated at provincial, regional or national scale in any country.

\section{References}

Ahmad N, Anjum GA. 2012. Legal and institutional perplexities hampering the implementation of urban development plans in Pakistan. Cities. 29:271-277.

Anand S, Sen A. 1994. Human development index: methodology and measurement [Internet]. New York; [cited 2016 Mar 25]. Available from: http://econpapers.repec.org/RePEc:hdr:hdocpa:hdocpa-1994-02 
Asian Development Bank. 2008. Managing Asian Cities: Sustainable and inclusive urban solutions [Internet]. Mandaluyong: Asian Development Bank. Available from: http://www.adb.org/sites/default/files/pub/2008/mac-report.pdf

Balisacan AM, Fuwa N. 2004. Going beyond Crosscountry Averages: Growth, Inequality and Poverty Reduction in the Philippines. World Dev. 32:1891-1907.

Bhatti SS, Tripathi NK, Nitivattananon V, Rana IA, Mozumder C. 2015. A multi-scale modeling approach for simulating urbanization in a metropolitan region. Habitat Int. 50:354-365.

Birdsall N, Londoño J. 1997. Asset inequality matters: an assessment of the World Bank's approach to poverty reduction. Am Econ Rev [Internet]. [cited 2016 Jun 5]. Available from: http://www.jstor.org/stable/2950879

Castells-Quintana D. 2016. Malthus living in a slum: Urban concentration, infrastructure and economic growth. J Urban Econ. 92:31-47.

Castells-Quintana D, Royuela V. 2017. Tracking positive and negative effects of inequality on long-run growth. Empir Econ.:1-30.

Conceição P, Galbraith J. 1998. Constructing long and dense time-series of inequality using the Theil index [Internet]. New York; [cited 2016 Jun 5]. Available from: http://papers.ssrn.com/sol3/papers.cfm?abstract_id $=148008$

Easterly W. 2007. Inequality does cause underdevelopment: Insights from a new instrument. J Dev Econ. 84:755-776.

Estes RJ, Morgan JS. 1976. World Social Welfare Analysis: a Theoretical Model. Int Soc Work. 19:29-41.

Fosu A. 2011. Growth, inequality, and poverty reduction in developing countries: recent global evidence [Internet]. Manchester: Brooks World Poverty Institute, University of Manchester; [cited 2016 Jun 5]. Available from: http://papers.ssrn.com/sol3/papers.cfm?abstract_id $=1813968$

Frenkel A, Ashkenazi M. 2008. Measuring urban sprawl: how can we deal with it? Environ Plan B Plan Des. 35:56-79.

Goh C, Luo X, Zhu N. 2009. Income growth, inequality and poverty reduction: A case study of eight provinces in China. China Econ Rev. 20:485-496.

Gordon P, Richardson H. 2000. Critiquing sprawl's critics [Internet]. Washington D.C.: Cato Institute; [cited 2016 Apr 22]. Available from: http://wwwbcf.usc.edu/ pgordon/pdf/pa365.pdf

Government of Punjab. 2001. Punjab Local Government Ordinance 2001. Islamabad.

Habibi S, Asadi N. 2011. Causes, results and methods of controlling urban sprawl. Procedia Eng. 21:133-141.

Hameed R, Nadeem O. 2006. Challenges of implementing urban master plans: the lahore experience. Proc World Acad Sci Eng Technol [Internet]. [cited 2016 Jun 5]; 17:335-342. Available from:

http://citeseerx.ist.psu.edu/viewdoc/download?doi=10.1.1.307.7582\&rep=rep1\&t ype $=$ pdf

Hardoy J, Mitlin D, Satterthwaite D. 2013. Environmental problems in an urbanizing world: finding solutions in cities in Africa, Asia and Latin America. London: Earthscan.

Henderson V. 2003. The urbanization process and economic growth: The so-what question. J Econ Growth. 8:47-71.

Hicks DA. 1997. The inequality-adjusted human development index: A constructive proposal. World Dev. 25:1283-1298. 
Holtz-Eakin D, Schwartz AE. 1995. Infrastructure in a structural model of economic growth. Reg Sci Urban Econ. 25:131-151.

Irwin EG, Bockstael NE. 2004. Land use externalities, open space preservation, and urban sprawl. Reg Sci Urban Econ. 34:705-725.

Jaeger JAG, Bertiller R, Schwick C, Kienast F. 2010. Suitability criteria for measures of urban sprawl. Ecol Indic. 10:397-406.

Kessides C. 1993. The contributions of infrastructure to economic development: a review of experience and policy implications. Kessides C, editor. Washington D.C.: World Bank Publications.

Korpi W, Palme J. 1998. The paradox of redistribution and strategies of equality: Welfare state institutions, inequality, and poverty in the Western countries. Am Sociol Rev. 63:661-687.

Kuznets S. 1955. Economic growth and income inequality. Am Econ Rev. 45:1-28.

Lewis BD. 2014. Urbanization and Economic Growth in Indonesia: Good News, Bad News and (Possible) Local Government Mitigation. Reg Stud. 48:192-207.

Lewis WA. 1954. Economic Development with Unlimited Supplies of Labour. Manchester Sch [Internet]. 22:139-191. Available from: http://doi.wiley.com/10.1111/j.1467-9957.1954.tb00021.x

Liu Y, Lu S, Chen Y. 2013. Spatio-temporal change of urban-rural equalized development patterns in China and its driving factors. J Rural Stud. 32:320-330.

Morris MD. 1979. Measuring the condition of the world's poor: The physical quality of life index. New York: Pergamon Press.

Moser CON. 1998. The asset vulnerability framework: Reassessing urban poverty reduction strategies. World Dev. 26:1-19.

Njoh AJ. 2003. Urbanization and development in sub-Saharan Africa. Cities. 20:167174.

Pakistan Bureau of Statistics. 1998. Census Report of Pakistan 1998 [Internet]. Islamabad. Available from: http://www.pbs.gov.pk/population-tables

Planning Commission Government of Pakistan. 1983. The Sixth five year plan 1983-88. Islamabad.

Punjab Bureau of Statistics. 2004. Multiple Indicator Cluster Survey 2003-2004

[Internet]. Lahore. Available from: http://www.bos.gop.pk/publicationreports

Punjab Bureau of Statistics. 2005. Punjab Development Statistics 2005 [Internet].

Lahore. Available from: http://www.bos.gop.pk/publicationreports

Punjab Bureau of Statistics. 2008. Punjab Development Statistics Report 2008

[Internet]. Lahore. Available from: http://www.bos.gop.pk/publicationreports

Punjab Bureau of Statistics. 2009. Multiple Indicator Cluster Survey 2007-2008 [Internet]. Lahore. Available from: http://www.bos.gop.pk/publicationreports

Punjab Bureau of Statistics. 2011. Multiple Indicator Cluster Survey 2011 [Internet]. Lahore. Available from: http://www.bos.gop.pk/publicationreports

Punjab Bureau of Statistics. 2012. Punjab Development Statistics Report 2012 [Internet]. Lahore. Available from: http://www.bos.gop.pk/publicationreports

Punjab Bureau of Statistics. 2015. Punjab Development Statistics 2015 [Internet]. Lahore. Available from: http://www.bos.gop.pk/publicationreports

Rana IA. 2014. Rural urban development dispsarity in Lahore city region: Policy implications for regional development. Khlong Laung: Asian Institute of Technology, Thailand. 
Rana IA, Bhatti SS, e Saqib S. 2017. The spatial and temporal dynamics of infrastructure development disparity - From assessment to analyses. Cities. 63:20-32.

Ravallion M. 2001. Growth, Inequality and Poverty: Looking Beyond Averages. World Dev. 29:1803-1815.

Roberts B, Kanaley T. 2006. Overview: Urbanization and sustainable development. In: Roberts B, Kanaley T, editors. Urban Sustain Asia Case Stud good Pract. Mandaluyong: Asian Development Bank; p. 1-13.

Roberts BH. 2014. Managing systems of secondary cities: Policy responses in international development [Internet]. Brussels: Cities Alliance/UNOPS. Available from: http://www.citiesalliance.org/node/4978

Rondinelli D. 1983. Dynamics of growth of secondary cities in developing countries. Geogr Rev.

Rouf M, Jahan S. 2007. Spatial and temporal patterns of urbanization in Bangladesh. Dhaka; [cited 2016 Mar 25]. Available from: www.bip.org.bd/SharingFiles/journal_book/20130718114655.pdf

Schweikert A, Chinowsky P, Kwiatkowski K, Espinet X. 2014. The infrastructure planning support system: Analyzing the impact of climate change on road infrastructure and development. Transp Policy. 35:146-153.

Shah S, Afridi, Minallah. 2007. Assessment of institutional arrangement for urban land development and management in five large cities of Punjab [Internet]. Lahore. Available from: http://www.urbanunit.gov.pk/PublicationDocs/28.pdf

Shorrocks A, Hoeven R Van der. 2005. Growth, inequality, and poverty: Prospects for pro-poor economic development. Oxford: Oxford University Press.

The Whoqol Group. 1998. The World Health Organization quality of life assessment (WHOQOL): Development and general psychometric properties. Soc Sci Med. 46:1569-1585.

Theil H, Raj B, Koerts J. 1992. Henri Theil's Contributions to Economics and Econometrics: Econometric theory and methodology. Vol. I. Dordrecht: Kluwer Academic Publishers.

United Nations. 2014. World Urbanization Prospects 2014: Highlights. New York: United Nations Publications.

Williamson J. 1965. Regional inequality and the process of national development: a description of the patterns. Econ Dev Cult Change [Internet]. [cited 2016 Jun 5]. Available from: http://www.jstor.org/stable/1152097

Yitzhaki S. 1983. On an extension of the Gini inequality index. Int Econ Rev (Philadelphia) [Internet]. [cited 2016 Jun 5]. Available from: http://www.jstor.org/stable/2648789 